\title{
Differentiation of chicken gonad as an endocrine organ: expression of LH receptor, FSH receptor, cytochrome P450c17 and aromatase genes
}

\author{
Y. Akazome, T. Abe and T. Mori \\ Department of Biological Sciences, Graduate School of Science, University of Tokyo, \\ Bunkyo-ku, Tokyo 113-0033, Japan
}

\begin{abstract}
The gonad is an endocrine organ secreting sex hormones and also a target of pituitary gonadotrophins. The expression of mRNAs encoding LH receptor (LHR), FSH receptor (FSHR), P450c17 and P450aromatase in the developing gonads of embryos between day 4 and day 6 of incubation was determined using a RT-PCR to elucidate the chicken gonad as a target organ of gonadotrophins. Although expression of mRNAs encoding LHR, FSHR and P450c17 was detected at day 4 of incubation in both sexes, mRNA encoding P450aromatase appeared at day 6 in female
\end{abstract}

\section{Introduction}

In avian species, oestrogen is a vital factor in the sexual differentiation of the gonads. In the developing ovary, oestrogen induces the proliferation of ovarian cortical cords (Scheib, 1983). The inhibition of P450aromatase can cause complete sex reversal (female to male) in chicken embryos (Elbrecht and Smith, 1992). Although intact male embryos do not express P450aromatase mRNA, oestrogen treatment on day 5 of incubation brings about P450aromatase expression in the testis of embryos on day 14 (Nakabayashi et al., 1997).

Sex steroid production is regulated by two pituitary glycoprotein hormones, $\mathrm{LH}$ and $\mathrm{FSH}$. In female chicken embryos, treatment with equine $\mathrm{LH}$ increases the concentrations of plasma oestradiol on day 7.5 of incubation (Woods et al., 1981), and treatment with hCG stimulates the production of testosterone and oestrogen on day 8 (Teng and Teng, 1977). These findings might imply the significance of gonadotrophins in gonadal steroidogenesis in chicken embryo. However, in hypophysectomized chicken embryos, the ovary secretes oestrogen up to days 16-18 of incubation (Weniger and Zeis, 1987; Weniger et al., 1989; Johnson, 1990), indicating autonomous ovarian oestrogen production during the first two-thirds of incubation. Therefore, the expression of chicken gonadotrophin receptor genes has been studied by several groups in an attempt to elucidate the establishment of the pituitary-gonadal axis in chicken embryos. In situ hybridization demonstrated that, in chicken embryos, cells containing mRNA encoding LH receptor

Email: zome@biol.s.u-tokyo.ac.jp embryos only, indicating that mRNAs encoding gonadotrophin receptors can be identified before sexual differentiation. Quantitative PCR analysis revealed that expression of mRNA encoding LHR and FSHR remained low in male gonads from day 4 to day 6 of incubation, whereas they increased on day 6 in female gonads. The sexual dimorphism in the expression of mRNAs encoding LHR and FSHR was confirmed in the sexually differentiated gonads of embryos at day 12 of incubation (LHR in ovary: LHR in testis $=7: 1$; FSHR in ovary: FSHR in testis $=9: 1$ ).

(LHR) appear from day 7 in the ovary, and from day 14 in the testis (Akazome et al., 1997) and that the earlier expression of mRNA encoding LHR in the ovary may be related to earlier oestrogen production in females. Mao et al. (2000) have quantified chicken embryonic LHR and FSHR gene expression from day 10 of incubation to day 14 after hatching using northern hybridization. Expression of mRNA encoding LHR was higher in left ovaries than in left testes from day 10 to day 18 of incubation, whereas it was higher in left testes than in left ovaries of 7-day-old chicks, possibly reflecting the gonadal activity in steroidogenesis (Mao et al., 2000). In contrast, little is known about expression of mRNA encoding LHR and FSHR in the gonads before the sexual differentiation (before day 7). The structures of cDNA encoding chicken LHR (Mizutani et al., 1998) and FSHR (You et al., 1996; Wakabayashi et al., 1997) have been reported, and facilitate more precise analyses of the expression of chicken gonadotrophin receptor genes.

The aim of the present study was to determine the day of onset of LHR and FSHR gene expression in chicken embryos during the formation of the gonads. The results were compared with those on the expression of steroidogenic enzymes to further understanding of gonadal development from an endocrinological perspective.

\section{Materials and Methods}

\section{Chicken embryos}

Fertilized eggs of the White Leghorn chicken were purchased from a commercial source (Miyake Furanjo, Chiba). The eggs were incubated with agitation (one stroke 
per $2 \mathrm{~h}$ ) at $37.5^{\circ} \mathrm{C}$ and $58-69 \%$ humidity. At days 4, 5, 6 and 12 of incubation, embryos were dissected to collect gonadal tissue. The paired gonads of embryos at days 5, 6 and 12 of incubation were removed from the mesonephric organ with a fine needle, whereas whole Wolffian bodies including gonadal rudiments were taken from embryos at day 4 of incubation. Embryos at days 4, 5 and 6 of incubation were estimated to be at stages 23-24, 26 and 28-29, respectively, according to the criteria of Hamburger and Hamilton (1951). The variance in stage among the samples collected on the same day may be the result of the storage temperature, time during transport or tissue collection, or a combination of these factors.

\section{Sexing of embryos}

The sex of the embryos was determined according to the presence of chromodomain-helicase DNA-binding protein W-linked (CHD-W) and related Z-linked (CHD-Z) genes (Griffiths et al., 1996; Griffiths and Korn, 1997). Genomic DNA was isolated from liver tissue as follows. A $10-30 \mathrm{~mm}^{3}$ piece of embryonic liver was digested with proteinase $\mathrm{K}$ at $37^{\circ} \mathrm{C}$ for $1 \mathrm{~h}$ in DNA extraction buffer $(50 \mathrm{mmol}$ Tris- $\mathrm{HCl} \mathrm{I}^{-1}$, $\mathrm{pH} 8.0,50 \mathrm{mmol}^{\mathrm{EDTA} \mathrm{I}} \mathrm{I}^{-1}$, and $2 \%$ (w/v) SDS) containing $10 \mu \mathrm{g}$ ribonucrease $\mathrm{A} \mathrm{ml}^{-1}$ (Sigma, St Louis, MO) with vigorous shaking. The tissue suspension was extracted once with phenol, and the DNA was recovered by ethanol precipitation. DNA fragments of CHD-W and CHD-NW genes were amplified by PCR using a set of primers as described by Griffiths et al. (1996). These two types of cDNA fragment were distinguished by the presence or absence of a Haelll recognition sequence. The specimen containing the $C H D-W$ gene was determined to be female.

\section{RNA preparation}

Tissue samples from each embryo were dissected and immediately placed in $20 \mu$ l cold extraction buffer, ISOGEN (Nippon gene Co. Ltd, Tokyo). Samples were stored at $-30^{\circ} \mathrm{C}$, and the gender of each embryo was examined as stated above. RNA was extracted individually to determine the onset of gene expression. After thawing, $5 \mu$ l chloroform was added to each sample and mixed vigorously until an emulsion was formed (about $15 \mathrm{~s}$ ). Samples were centrifuged at $10000 \mathrm{~g}$ at $4^{\circ} \mathrm{C}$ for $15 \mathrm{~min}$ and the aquatic fraction was collected. Then, glycogen carrier was added to the fraction at $200 \mu \mathrm{g} \mathrm{ml}^{-1}$ (final concentration), and RNA was precipitated at $4^{\circ} \mathrm{C}$ with a twofold concentration of ethanol. Total RNA was deposited by spinning, rinsed with $70 \%(\mathrm{v} / \mathrm{v})$ cold ethanol, and resuspended in $15 \mu \mathrm{l}$ diethylpyrocarbonate-treated water. The amount of RNA recovered from each tissue was estimated from the value of the UV absorbance at $260 \mathrm{~nm}$, detected by spectrophotometer to be 264-5988 ng.

Nine to thirteen pairs of gonads were pooled for RNA extraction to quantify the amount of mRNA in embryos at day 4 to day 6 of incubation. RNA of embryos at day 12 of incubation was extracted individually.

\section{Reverse transcription (RT)}

The onset of gene expression was determined by reverse transcription of 88-300 ng total RNA into first-strand cDNA in a $15 \mu \mathrm{l}$ mixture containing $50 \mathrm{mmol}$ Tris- $\mathrm{HCl} \mathrm{I}^{-1}$ (pH 8.3), $75 \mathrm{mmol} \mathrm{KCl} \mathrm{I}^{-1}, 15 \mathrm{mmol} \mathrm{MgCl}_{2} \mathrm{I}^{-1}, 10 \mathrm{mmol}$ dithiothreitol $\mathrm{I}^{-1}$ (Gibco BRL, Rockville, MD), 15 iu ribonuclease inhibitor (Wako, Osaka), $1 \mathrm{mmol}$ each of dATP, dGTP, dTTP and dCTP I-1 (Amersham Pharmacia Biotech, Buckinghamshire), 10 ng random hexamer (Takara, Tokyo), and $100 \mathrm{iu}$ reverse transcriptase (Superscript RNaseH-, Gibco BRL). Three hundred nanogrammes of total RNA was transcribed with downstream gene-specific primers of LHR, 5'-GAATTTATCCAGAG-3' (corresponding to $767 \leftarrow 779$; Mizutani et al., 1998) and FSHR, 5'TGTAAATG-CACAGC-3' (corresponding to $798 \leftarrow 815$; Wakabayashi et al., 1997) to quantify the amounts of mRNA encoding LHR and FSHR. The reaction was performed at $42^{\circ} \mathrm{C}$ for $1 \mathrm{~h}$, and then samples were incubated at $90^{\circ} \mathrm{C}$ for $10 \mathrm{~min}$ to inactivate the reverse transcriptase. The remainder of each RNA sample was incubated with water instead of reverse transcriptase to monitor the amplification of any contaminating genomic DNA.

\section{PCR amplification}

A half microlitre of each $\mathrm{RT}$ reaction mixture was subjected to PCR amplification. The $10 \mu \mathrm{l}$ reaction mixture consisted

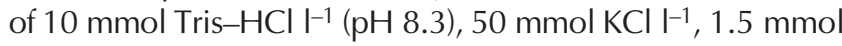
$\mathrm{MgCl}_{2} \mathrm{I}^{-1}, 0.2 \mathrm{mmol}$ each of dATP, dGTP, dTTP and dCTP I-1, and $1 \mu \mathrm{mol}$ each of sense and antisense primers $\mathrm{I}^{-1}$. At first, mixtures were heated to $94^{\circ} \mathrm{C}$ for $1 \mathrm{~min}$, and then PCR was performed for 30 cycles. The cycling profile was $30 \mathrm{~s}$ denaturation at $94^{\circ} \mathrm{C}, 15 \mathrm{~s}$ annealing at the relevant temperature (Table 1), and $15 \mathrm{~s}$ elongation at $72^{\circ} \mathrm{C}$, followed by a final extension step at $72^{\circ} \mathrm{C}$ for $4 \mathrm{~min} 45 \mathrm{~s}$. The primers used were designed to flank an intron to eliminate the possibility of the amplification of contaminating genomic DNA. Seven sets of primer pairs for the mRNAs encoding $\beta$-actin, P450c17, P450aromatase, extracellular region of LHR (LHREC), transmembrane region of LHR (LHRTM), extracellular region of FSHR (FSHREC) and transmembrane region of FSHR (FSHRTM) were custom-made by Nippon Seihun, Co. Ltd (Tokyo). Primer pairs for extracellular and transmembrane domains of LHR and FSHR were prepared independently to detect the possible time lag of the onset of the gene expression between these domains. The primer sequences and the localization of annealing sites are represented (Table 1). The PCR products were separated in a $2 \%(\mathrm{w} / \mathrm{v})$ agarose gel and visualized by ethidium bromide staining.

Internal restriction enzyme cleaving sites, Sau3AI (1393 of $\mathrm{P} 450_{\mathrm{C} 17}$; Ono, et al., 1988), Haelll (1393 of P450aromatase; McPhaul et al., 1988), EcoRV (610 of LHREC; Mizutani et al., 1998), Mspl (1118 of LHRTM; Mizutani et al., 1998), EcoRI (770 of FSHREC; Wakabayashi et al., 1997) and Pstl (993 of FSHRTM; Wakabayashi et al., 1997), were used to confirm the proper amplification of the cDNA fragment (Fig. 1). 
Chicken LHR cDNA

\begin{tabular}{|c|c|c|c|}
\hline & 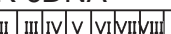 & & \\
\hline
\end{tabular}

Chicken FSHR cDNA

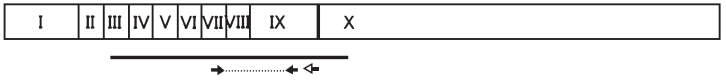

Fig. 1. Positions of cDNA fragments used for RNA standards (bars) and primers used for RT (white arrows) and PCR (black arrows). The numbers I-XI in the white boxes indicate exon numbers of chicken LH receptor (LHR; Mizutani, et al., 1998) and FSH receptor (FSHR; Wakabayashi, et al., 1997).

\section{Quantification of the LHR and FSHR mRNAs}

The amount of mRNA encoding LHR and FSHR in gonadal tissues was determined by real-time PCR (LightCycler, Roche Diagnostics, Tokyo). The quail LHR and FSHR cDNA fragments inserted in the plasmid containing SP6 promoter were used as templates for generating the external standards. In vitro transcription was carried out as described by Akazome et al. (1994). The amount of RNA was estimated from the value of the absorbance at $260 \mathrm{~nm}$, and serial dilutions ranging from $10^{3}$ to $10^{10}$ molecules $\mu^{-1}$ were prepared. Messenger RNA-specific primers were used for the RT (LHR: 5'-GCTTCCAGCAGGCTG-3'; FSHR: 5'-TGTAAATGCACAGC-3'). The sets of specific primers used for PCR were 5'-GTTCCCAGACTTGACGCAGA-3' and 5'-GCCTGAGGTTTTTGTTGTCC-3' for LHR, and 5'-TGGAACCTGCCTGGATGAG-3' and 5'-GGATAGGT-GAAGTTTGCC-3' for FSHR. The localization of the external standards and primers using chicken cDNAs is represented (Fig. 1). In the amplified region, quail LHR has $97 \%$ similarity with chicken LHR, and quail FSHR has 96\% similarity with chicken FSHR. Next, $300 \mathrm{ng}$ sample RNA or $10^{3}-10^{10}$ molecules of standard RNA were reverse transcribed as mentioned above. Triplicate reverse-transcriptions were performed for RNA assay of the pooled samples from embryos at days 4, 5 and 6 of incubation to eliminate the potential bias caused by uneven sample loading. One microlitre of the RT reaction mixture was compounded with $0.5 \mu \mathrm{mol} \mathrm{I-1}$ of each of the primers, $4 \mathrm{mmol} \mathrm{MgCl}_{2}, \mathrm{I}^{-1}$ and $1 \times$ concentration of SYBR Green I (Roche), and the volume was adjusted to $10 \mu \mathrm{l}$ with sterile water. Forty cycles were performed. Each cycle consisted of denaturation at $94^{\circ} \mathrm{C}$ for $1 \mathrm{~s}$, except for the first incubation for $30 \mathrm{~s}$, primer annealing at $55^{\circ} \mathrm{C}$ for LHR or $64^{\circ} \mathrm{C}$ for FSHR for $20 \mathrm{~s}$, and elongation at $72^{\circ} \mathrm{C}$ for $5 \mathrm{~s}$. The quantity of amplified DNA fragments was measured as the strength of the emission from SYBR Green I binding to the DNA double strand. The initial concentrations of the cDNA of specimens were estimated by referring to the results of the standard using LightCycler 3.1 software (Roche).
Table 2. Summary of expression of chicken embryonic P450c17, P450aromatase, $\mathrm{LH}$ receptor (LHR) and FSH receptor (FSHR) analysed by RT-PCR

\begin{tabular}{lllll}
\hline & & \multicolumn{3}{c}{ Day of incubation } \\
\cline { 3 - 5 } & & Day 4 & Day 5 & Day 6 \\
\hline \multirow{2}{*}{$\beta$-actin } & Female & $5 / 5$ & $3 / 3$ & $5 / 5$ \\
\multirow{2}{*}{ P450c17 } & Male & $4 / 4$ & $4 / 4$ & $3 / 3$ \\
\multirow{2}{*}{ P450aromatase } & Female & $1 / 5$ & $0 / 3$ & $2 / 5$ \\
\multirow{2}{*}{ LHREC } & Male & $2 / 4$ & $3 / 4$ & $2 / 3$ \\
& Female & $0 / 5$ & $0 / 3$ & $4 / 5$ \\
LHRTM & Male & $0 / 4$ & $0 / 4$ & $0 / 3$ \\
& Female & $4 / 5$ & $3 / 3$ & $5 / 5$ \\
FSHREC & Male & $4 / 4$ & $4 / 4$ & $3 / 3$ \\
& Female & $4 / 5$ & $2 / 3$ & $5 / 5$ \\
FSHRTM & Male & $4 / 4$ & $4 / 4$ & $3 / 3$ \\
& Female & $5 / 5$ & $3 / 3$ & $5 / 5$ \\
& Male & $4 / 4$ & $4 / 4$ & $2 / 3$ \\
& Female & $4 / 5$ & $1 / 3$ & $4 / 5$ \\
& Male & $2 / 4$ & $4 / 4$ & $2 / 3$ \\
\hline
\end{tabular}

Values are number of positive specimens/number of specimens analysed.

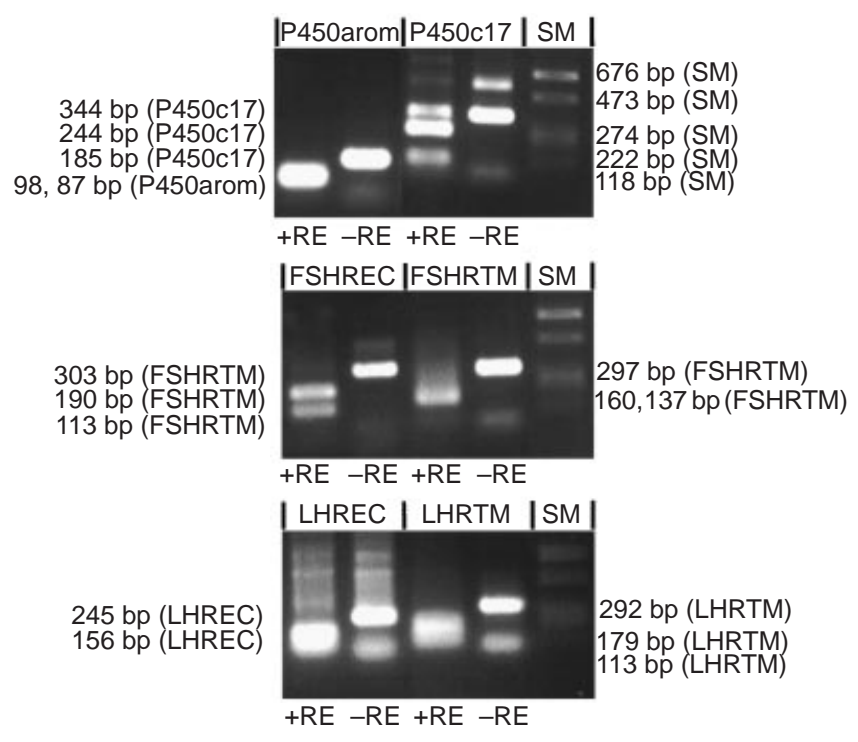

Fig. 2. Amplification by RT-PCR of CDNA fragments from P450c17, P450aromatase (P450arom), extracellular and transmembrane parts of $\mathrm{LH}$ receptor (LHREC and LHRTM, respectively) and extracellular and transmembrane parts of FSH receptor gene transcripts. The specificity of amplification was verified by digestion with the restriction enzyme (RE+) (see Table 1). The size marker (SM) was generated by double digesting the plasmid pUC118 with restriction enzymes Afal and Avall (Takara, Tokyo).

The quantity of mRNA encoding LHR and FSHR per $\mu \mathrm{g}$ total gonadal RNA in embryos at days 4-6 was represented as the mean value of triplicate analyses, whereas that in embryos at day 12 was expressed as the 


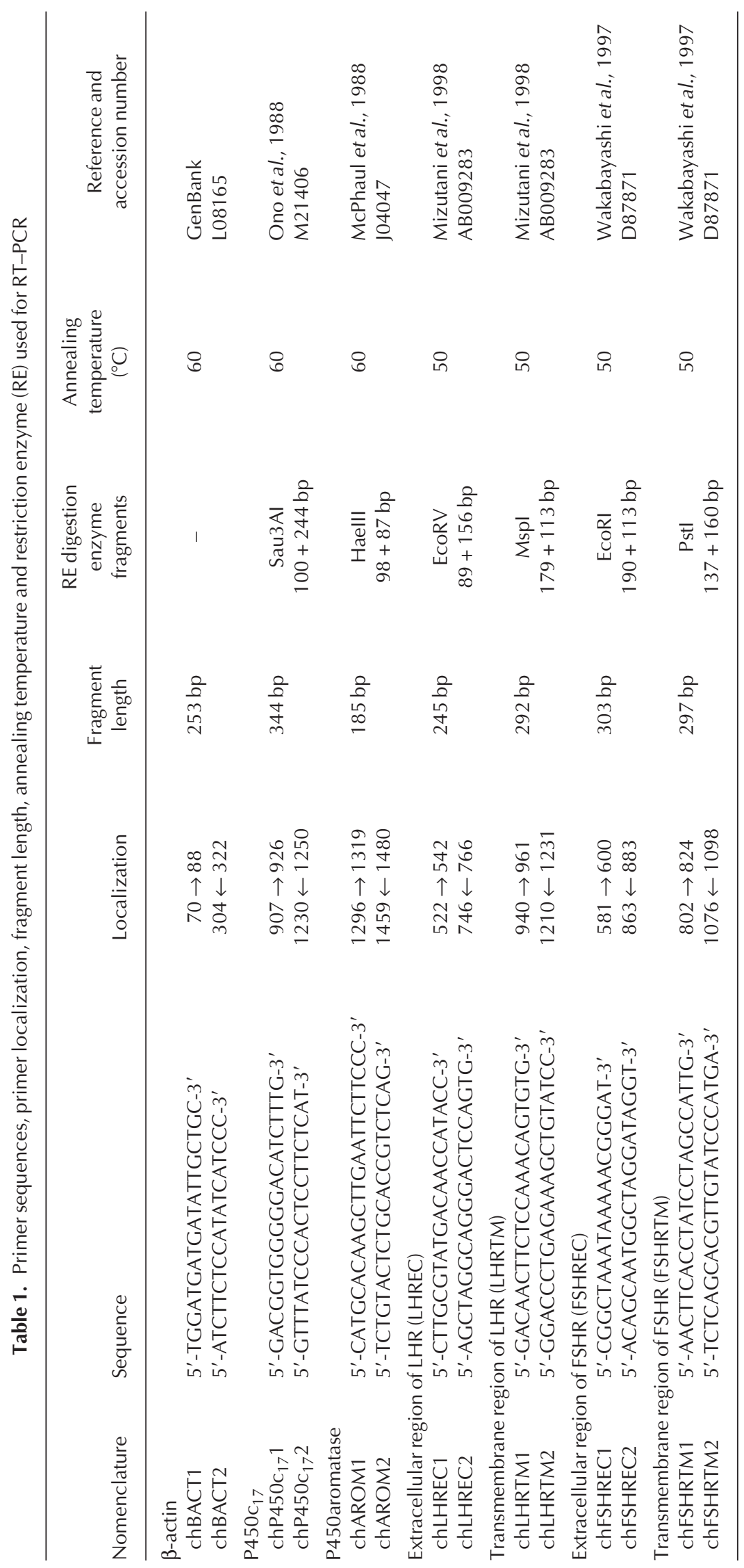


(a)

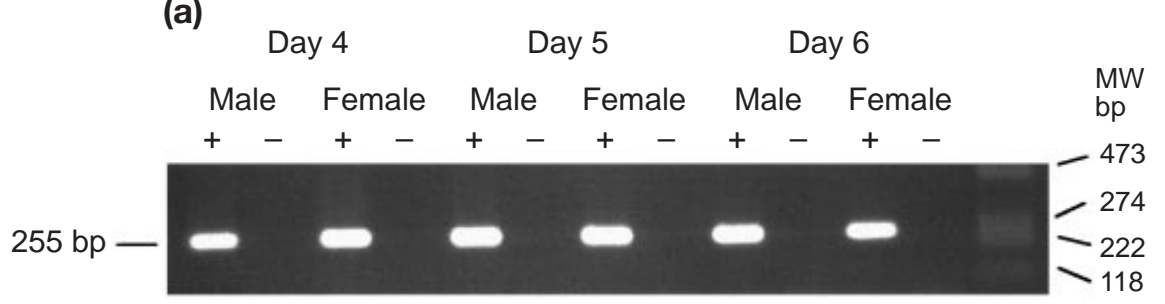

(b)

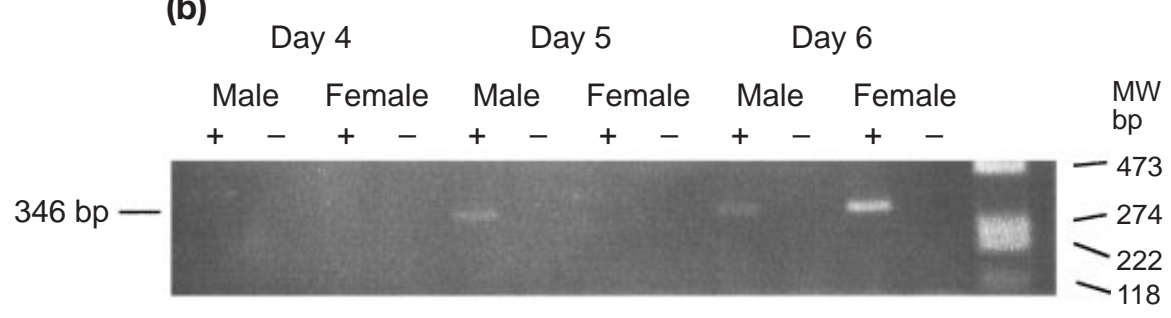

(c)

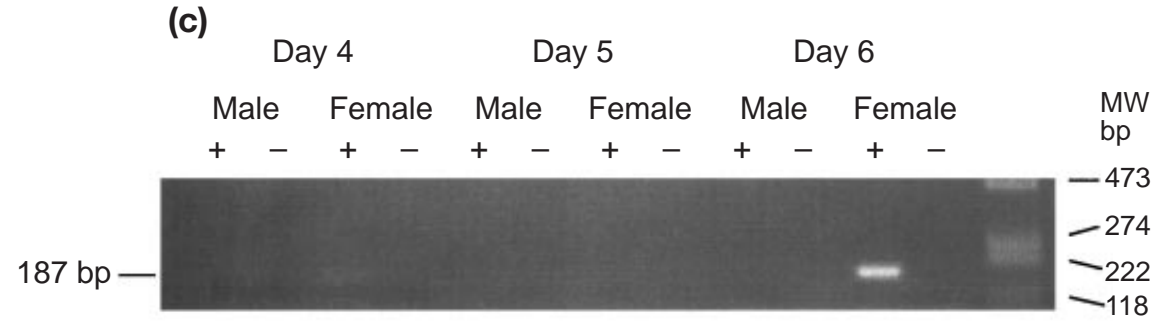

Fig. 3. Expression of mRNA encoding chicken (a) $\beta$-actin, (b) P450c17 and (c) P450aromatase between day 4 and day 6 of incubation detected by PCR with (+) or without (-) reverse transcription. In (b) very faint bands amplified from cDNA encoding $\mathrm{P} 450 \mathrm{c} 17$ are visible in both sexes, whereas in (a) prominent bands of $\beta$-actin are obtained from all samples reverse transcribed. However, the P450aromatase gene transcript is detected specifically in day 6 females. MW: molecular weight marker.

mean value of samples from individual specimens (testis: $n=4$; ovary: $n=3$ ). Student's $t$ test was applied to determine the significance of the difference in the amount of mRNA encoding LHR in embryos at day 12 , since a similar variance was supposed. However, the amount of mRNA encoding FSHR in embryos at day 12 was analysed by Welch's $t$ test, since a similar variance was not supposed.

\section{Results}

The expression of mRNAs encoding P450c17, P450aromatase, LHR and FSHR was detected by RT-PCR using sets of primers (Table 2). In all cases, fragments of predicted length were obtained, and the specificity of amplification was verified by digestion with the restriction enzymes listed (Table 1; Fig. 2). Messenger RNA encoding P450c17 was detected on day 4 in one of five female and two of four male gonads, although the amplification was very weak. On day 5 , mRNA encoding P450c17 was detected in males but not in females. On day 6 , two of five female and two of three male gonads expressed mRNA encoding P450c17 (Fig. 3b).
However, mRNA encoding P450aromatase was detected in day 6 female gonads only (Fig. 3c), whereas the $\beta$-actin transcripts were amplified successfully in all of the samples (Fig. 3a).

The gene expression of both the extracellular and transmembrane regions of LHR (LHREC and LHRTM) was detected in both sexes at day 4 of incubation, the earliest age at which samples were collected (Fig. 4a,b). Similarly, both regions of FSHR (FSHREC and FSHRTM) were expressed in the two sexes at day 4 of incubation (Fig. 4c,d). Full-length mRNA encoding LHR was detected on day 4 of incubation when the gonad is formed first from the genital ridge (Table 2).

Expression of mRNA encoding LHR remained very low from day 4 to day 6 , although it increased in female gonads on day 6 . On day 12 , the amount of mRNA encoding LHR per $\mu$ g testicular and ovarian RNA reached $(3.06 \pm 1.06)$ $\times 10^{7}$ (mean value \pm standard error) molecules and $(2.25 \pm 0.16) \times 10^{8}$ molecules, respectively. The difference between mRNA encoding testicular and ovarian LHR was significant (Student's $t$ test: $P<0.01$; Fig. 5a). Expression of mRNA encoding FSHR remained very low from day 4 to day 
(a)

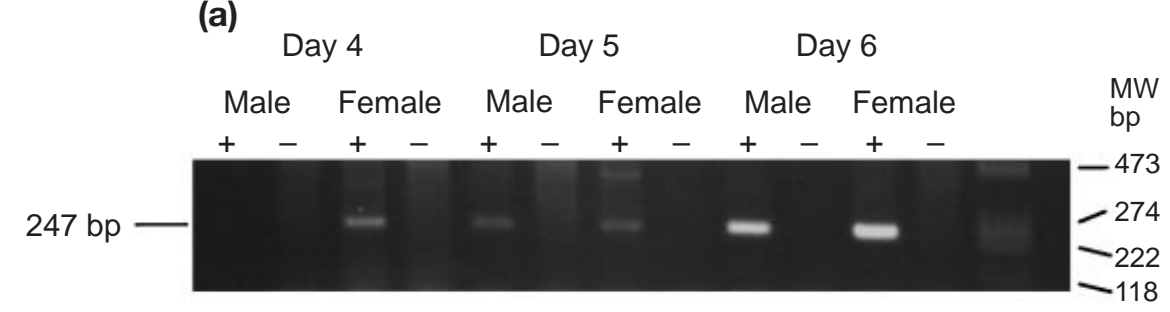

(b)

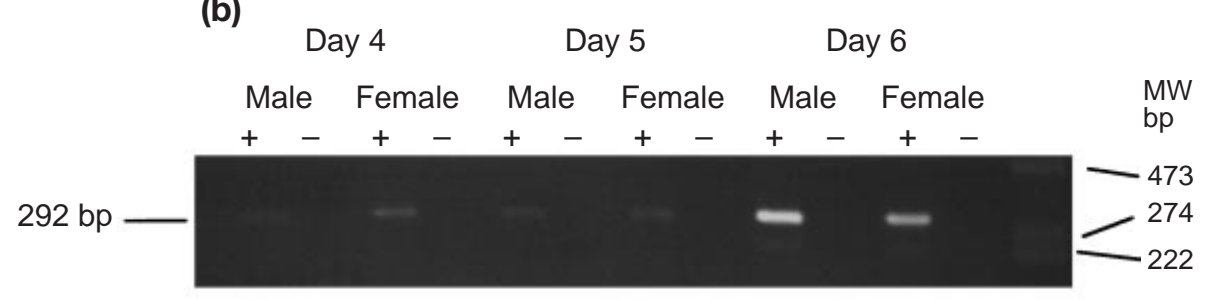

(c)

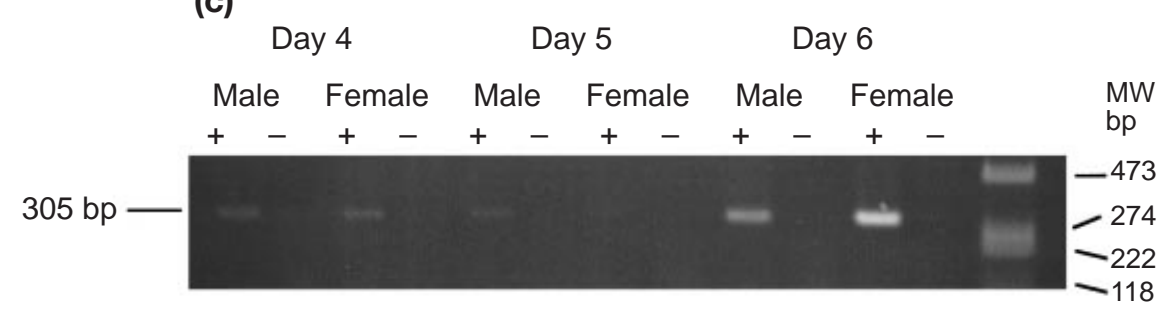

(d)

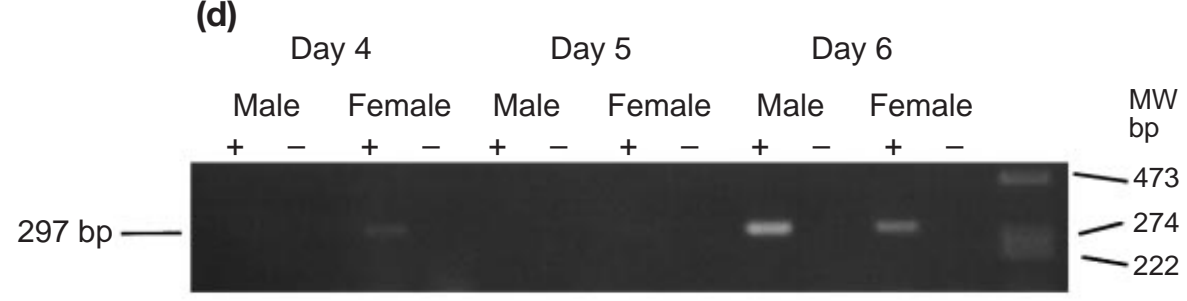

Fig. 4. Expression of mRNA encoding chicken extracellular and transmembrane regions of LH receptor ((a) LHREC and (b) LHRTM) and FSH receptor ((c) FSHREC and (d) FSHRTM) between day 4 and day 6 of incubation. Very weak bands are visible in preparations from embryos at day 4 and day 6 , although several specimens yield no bands. Prominent bands are obtained from preparations from embryos at day 6 of incubation.

6. No significant differences were obvious between the sexes on days 4 and 5 , but expression of mRNA encoding FSHR increased in female gonads on day 6 . On day 12 , the amount of mRNA encoding FSHR contained in $1 \mu \mathrm{g}$ total RNA from testis and ovary reached $(2.16 \pm 0.73) \times 10^{7}$ molecules and $(1.95 \pm 0.48) \times 10^{8}$ molecules, respectively. The difference between the testicular and ovarian mRNA encoding FSHR was significant (Welch's $t$ test: $P<0.05$; Fig. 5b).

\section{Discussion}

The expression of two genes encoding steroidogenic enzymes and gonadotrophin receptors in chicken embryo gonads were analysed using RT-PCR. In female gonads, only one of five embryos at day 4 of incubation, and none of three embryos at day 5 of incubation expressed P450c17. This finding may be the result of low abundance of mRNA encoding P450c17 from day 4 to day 5 in female gonads (Yoshida et al., 1996; Nomura et al., 1999; Nishikimi et al., 2000). Messenger RNA encoding P450aromatase was detected first in female gonads on day 6 . These results are in agreement with previous findings (Yoshida et al., 1996; Smith et al., 1997; Nomura et al., 1999; Nishikimi et al., 2000). Messenger RNA encoding LHR was detected in most samples from both sexes between day 4 and day 6 . However, in situ hybridization showed that cells containing mRNA encoding LHR appear from day 7 in the ovary and 

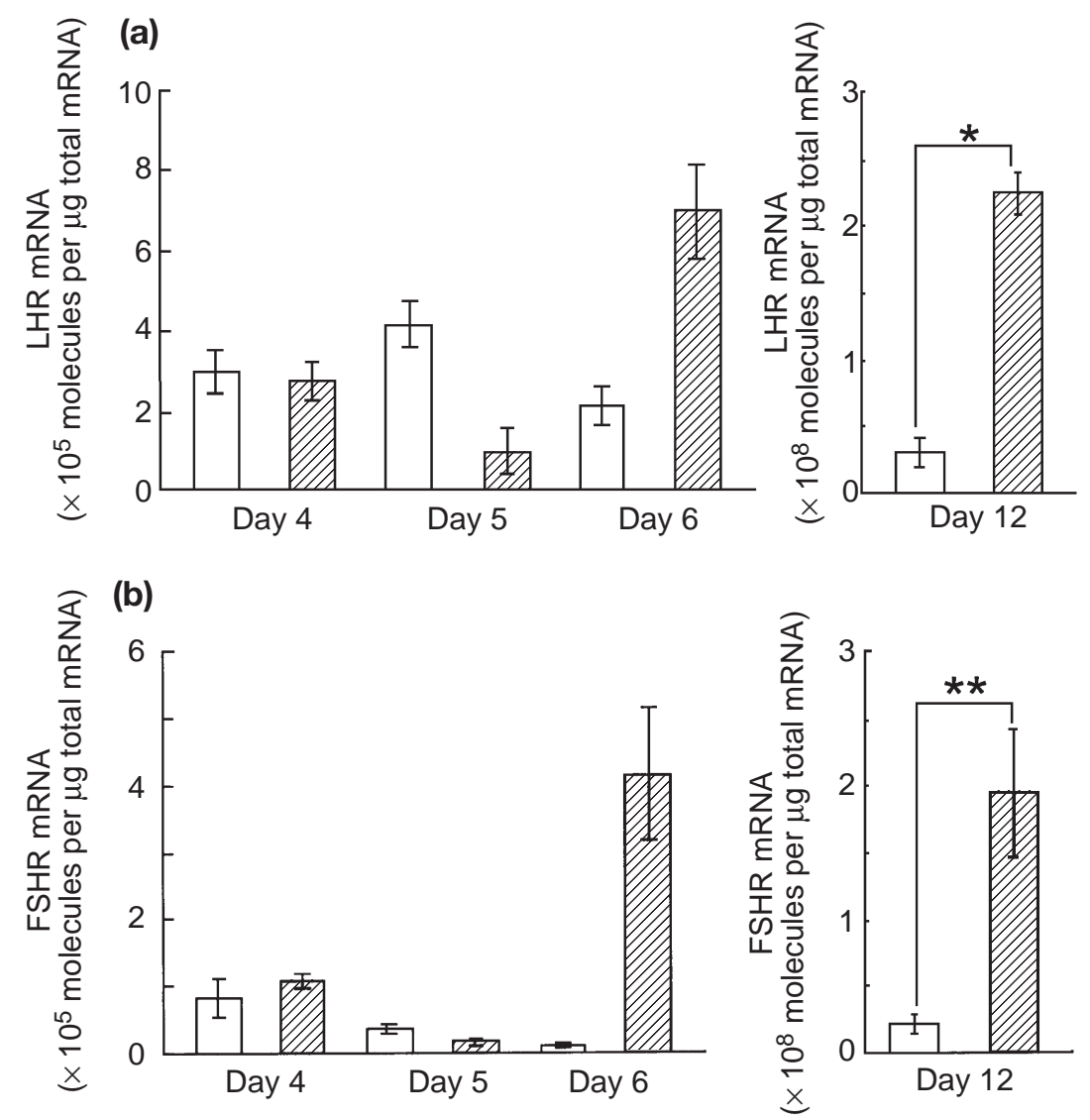

Fig. 5. (a) Abundance of mRNA encoding (a) LH receptor (LHR) and (b) FSH receptor (FSHR) in male $(\square)$ and female $(\square)$ gonads. Vertical bars represent the standard error. Asterisks represent significant differences between male and female: $* P<0.01$; $* * P<0.05$. Data from embryos at days 4,5 and 6 of incubation are presented as the mean of three trials using pooled samples of 9-13 pairs of gonads, and those from embryos day 12 are expressed as the mean of four (male) or three (female) pairs of gonads.

from day 14 in the testis (Akazome et al., 1997). The discrepancy between previous and present findings may be the result of differences in the sensitivities of the techniques used. In fact, quantitative PCR analysis revealed that the amount of ovarian mRNA encoding LHR was approximately sevenfold higher than that of testicular mRNA in day 12 specimens. These findings indicate that, in chicken embryos, the female gonads are likely to be more sensitive to $\mathrm{LH}$ than are the testes. In rats, before the onset of expression of the full-length mRNA encoding LHR, which occurred 7 days after birth in the ovary (Sokka et al., 1992) and on day 15.5 of fetal life in the testis (Zhang et al., 1994), transcripts encoding the extracellular part of the receptor are detected, that is, a non-functional receptor is expressed at first in rats. However, in chicken embryo, the mRNA encoding full-length LHR was detected from day 4, when gonad is first formed.

In the present study, mRNA encoding FSHR was expressed on day 4 of incubation. Before sexual differentiation (days 4-6 of incubation), the quantity of mRNA encoding FSHR was extremely low in both sexes. On days 4 and 5, there was no significant difference between males and females. On day 6, mRNA encoding P450aromatase was first detected in female gonads. Female gonads on days 6 and 12 showed a larger amount of mRNA encoding FSHR than did male gonads. Thus, sexual dimorphism was also evident in the expression of mRNA encoding FSHR. The results of several studies imply the independence of gonads from hypophyseal influence during the early stages of development. The gonads in chicken embryos hypophysectomized (decapitated) at 33-38 h of incubation develop up to day 13 (Fugo, 1940), and the ovary of embryos hypophysectomized by partial decapitation at 33-39 h of incubation secretes oestrogens up to days 16-18 (Weniger and Zeis, 1987; Weniger et al., 1989). Therefore, the expressions of LHR and FSHR during day 4 and day 6 should be independent of the pituitary gland.

In summary, low but detectable amounts of mRNA encoding LHR and FSHR were found in the gonads of both sexes as early as day 4 of incubation, when the gonad is first formed from the mesonephros. On day 6, when sexual differentiation is initiated in chicken gonads, the amounts of 
mRNA encoding LHR and FSHR in female gonads exceed those in male gonads. The larger quantities of mRNA encoding LHR and FSHR in female gonads on days 6 and 12 indicate that, in chickens, the female gonad differentiates earlier than the male gonad as a target organ of gonadotrophins.

This study was supported by research grants from the Ministry of the Environment, Japan, as well as the Takeda Scientific Foundation (Y. Akazome), and Grants-in-Aid for Scientific Research on Priority Areas (A) from the Ministry of Education, Culture, Sports, Science and Technology, Japan (T. Mori). The authors thank T. Kubo and S. Sasaki (University of Tokyo) for use of the light cycler and instruction in the performance of quantitative PCR analysis.

\section{References}

Akazome Y, Park MK, Mori T and Kawashima K (1994) Characterization of cDNA-encoding $\mathrm{N}$-terminal region of the quail lutropin receptor General and Comparative Endocrinology 95 222-231

Akazome Y, Yasugi S, Park MK and Mori T (1997) Ontogeny of the expression of messenger ribonucleic acid encoding lutropin receptor in chicken embryo Zoological Science 14 363-367

Elbrecht A and Smith RG (1992) Aromatase enzyme activity and sex determination in chickens Science 255 467-470

Fugo NW (1940) Effects of hypophysectomy in the chick embryo Journal of Experimental Zoology 85 271-297

Griffiths G and Korn RM (1997) A CHD1 gene is Z chromosome linked in the chicken Gallus domesticus. Gene 197 225-229

Griffiths G, Daan S and Dijkstra C (1996) Sex identification in birds using two CHD genes Proceedings of The Royal Society of London Series B $2631251-1256$

Hamburger V and Hamilton HL (1951) A series of normal stages in the development of the chick embryo Journal of Morphology 88 49-92

Johnson AL (1990) Steroidogenesis and actions of steroids in the hen ovary Poultry Biology 2 319-346

McPhaul MJ, Noble JF, Simpson ER, Mendelson CR and Wilson JD (1988) The expression of a functional cDNA encoding the chicken cytochrome P-450arom (aromatase) that catalyzes the formation of estrogen from the androgen Journal of Biological Chemistry 263 16 358-16 363

Mao X, Zhang C, Saito N and Shimada K (2000) Expression of messenger ribonucleic acids of luteinizing hormone and follicle-stimulating hormone receptors in the embryonic and posthatch gonads of the chicken Japanese Poultry Science 37 212-220

Mizutani T, Minegishi T, Nonobe Y, Abe Y, Hasegawa Y, Wakabayashi K, Kamiyoshi M, and Miyamoto K (1998) Molecular cloning and functional expression of chicken luteinizing hormone receptor Biochimica et Biophysica Acta 1397 1-8

Nakabayashi O, Nomura O, Kikuchi H, Kikuchi T and Mizuno S (1997) Estrogen synthesis and receptors during early gonadal development. In Perspectives in Avian Endocrinology pp 27-36 Eds S Harvey and RJ Etches. Society for Endocrinology, Bristol
Nishikimi H, Kansaku N, Saito N, Usami M, Ohno Y and Shimada K (2000) Sex differentiation and mRNA expression of P450c17, P450arom and $\mathrm{AMH}$ in gonads of the chicken Molecular Reproduction and Development 55 20-30

Nomura O, Nakabayashi O, Nishimori K, Yasue H and Mizuno S (1999) Expression of five steroidogenic genes including aromatase gene at early developmental stages of chicken male and female embryos Journal of Steroid Biochemistry and Molecular Biology 71 103-109

Ono H, Iwasaki M, Sakamoto $\mathbf{N}$ and Mizuno S (1988) cDNA cloning and sequence analysis of a chicken gene expressed during the gonadal development and homologous to mammalian cytochrome P-450c17 Gene 66 77-85

Scheib D (1983) Effects and role of estrogens in avian gonadal differentiation Differentiation 23 (Supplement) S87-S92

Smith CA, Andrews JE and Sinclair AH (1997) Gonadal sex differentiation in chicken embryos: expression of estrogen receptor and aromatase genes Journal of Steroid Biochemistry and Molecular Biology $\mathbf{6 0}$ 295-302

Sokka T, Hämäläinen T and Huhtaniemi I (1992) Functional LH receptor appears in the neonatal rat ovary after changes in the alternative splicing pattern on the LH receptor mRNA Endocrinology 130 1738-1740

Teng CT and Teng CS (1977) Studies on sex-organ development. The hormonal regulation of steroidogenesis and adenosine 3', 5'-cyclic monophosphate in embryonic-chick ovary Biochmical Journal 162 123-124

Wakabayashi N, Suzuki A, Hoshino H, Nishimori K and Mizuno S (1997) The cDNA cloning and transient expression of a chicken gene encoding a follicle-stimulating hormone receptor Gene 197 121-127

Weniger JP and Zeis A (1987) 17ß-estradiol secretion by the ovary of the hypophysectmized chick embryo General and Comaparative Endocrinology 65 9-11

Weniger JP, Chouraqui J and Zeis A (1989) 17ß-estradiol secretion in normal and hypophysectmized chick embryos Reproduction Nutrition Development 29 89-93

Woods JE, Mannela JA and Thommes RC (1981) The hypothalamicadenohypophyseal-gonadal axes in the developing chick embryo General and Comparative Endocrinology 45 66-73

Yoshida K, Shimada K, and Saito N (1996) Expression of P45017a hydroxylase and P450aromatase genes in the chicken gonad before and after sexual differentiation General and Comparative Endocrinology 102 233-240

You S, Bridgham JT, Foster DN and Johnson AL (1996) Characterization of the chicken follicle-stimulating hormone receptor (cFSH-R) complementary deoxyribonucleic acid, and expression of cFSH-R messenger ribonucleic acid in the ovary Biology of Reproduction 55 1055-1062

Zhang FP, Hämäläinen T, Kaipia A, Pakarinen P and Huhtaniemi I (1994) Ontogeny of luteinizing hormone receptor gene expression in the rat testes Endocrinology 134 2206-2213

Received 1 May 2001.

First decision 21 August 2001.

Final manuscript received 31 January 2002.

Accepted 31 January 2002. 